POLISH POLITICAL SCIENCE

VOL XL 2011

PL ISSN 0208-7375

\title{
ON FORMATION OF METHOD IN POLITICAL SCIENCE
}

\author{
by Andrzej Chodubski
}

It is widely recognised, that the status of any scientific discipline is vitally determined by its methodological autonomy. These are theoretical rules on the acquirement of information about a given reality, its definitions, systematization, clarification and interpretation. ${ }^{1}$ It is a specific challenge with regards to political science, which stems from the subject of knowledge, the politics. This realm is known to humanity from the onset of structure-shaping and institutionalisation of social life, and since ancient times attempts at its theoretical clarification are being undertaken. It has taken an important place within philosophical thought, historical and legal analysis. This reality led to political science becoming an integrating platform for knowledge from areas of political and social philosophy, law, economy, history. This integration has made cognitive challenges superficial and as a consequence raised such questions as: is political science a scientific discipline?2 The unfavourable image was revealed as it was

1 See B. Krauz-Mozer, Teorie polityki. Założenia metodologiczne, Warszawa 2005; T. Łoś-Nowak, Stosunki międzynarodowe. Teorie - systemy - uczestnicy, Wrocław 2006; D. Marsh, G. Stoker (eds.), Teorie i metody w naukach politycznych, Kraków 2006; A. Chodubski, Wstęp do badań politologicznych, Gdańsk 2008.

2 A. Heywood, Politologia, Warszawa 2008, chapter 1. 
included in broad process of political education of society. In presentation of political phenomena and processes the domination of a perspective based on colloquial social experience and political correctness - justification of phenomena and processes generated by agents of power - became overbearing. This reality was intensified under the conditions of mass media development. ${ }^{3}$ In a situation of superficial commenting of simultaneously becoming facts and phenomena of political life, the need for a methodological approach towards them was revealed. In addition, it has been recognised that not all knowledge is scientific knowledge, plus it has been pointed out: what is the difference between scientific and colloquial knowledge?

The cultural practice reveals that under the circumstances of reshaping informational order, methodological challenges remain on the level of slogans, as "ornament" to various studies and treatises. Therefore a challenge arises to appropriate a suitable importance to the method in political science, which would mean that ideas and theories from political science be used to explain phenomena and processes recognised by various disciplines of humanistic and social research. ${ }^{4}$

The method of political science faces a low level of acceptance, though, both endogenous and exogenous. It is mostly explained by the fact that political science is pursued by specialists from different disciplines, among them jurists, historians, economists, theologians, military servicemen, who superficially identify themselves with political science, yet frequently have a distrustful attitude towards its tools. An unfavourable stance regarding the autonomy of political science is displayed by the representatives of closely related disciplines of social and natural science. They point out the accession of political scientists to ideological and political life, resulting at the same time in replacing the truth about reality with political correctness. They criticise the reduction of the empirical research's scope to a minimum.

Faced with this situation, political scientists frequently express the opinion that their discipline, interdisciplinary by its nature, does not have

\footnotetext{
3 T. Klementewicz, Spór o model metodologiczny nauki o polityce, Warszawa 1891, p. 11.

4 A. Chodubski, Wstęp do badań..., pp. 116-117.
} 
to employ a separate methodology, by which it is "excused" from complying with the principles of methodological exclusiveness.

Currently, the following are regarded as essential conditions under which the method of political science can be realised: ${ }^{5}$

1. existence of a group of researchers who identify themselves completely with political science; recognising their autonomy from other scientific disciplines;

2. functioning of state-run or private institutions, that pursue political science on purely scientific or didactic level and popularise the results of current research;

3. gaining acceptance for the activity of political science from other scientific disciplines, especially those closely related;

4. revealing the interest in political science education and research in this field by university candidates and students;

5. openness to recognition of the international standards in the field of political science research.

The accomplishment of these challenges under the conditions of Polish culture and civilization is not simple. To a large measure this is the result of staff issues. ${ }^{6}$ Academics in many institutions of political science education hold non-political science degrees (they are jurists, historians, economists); in their professional identification they do not display strong bonds with political science, which is also expressed in their scientific and didactic output. In their research work they do not orientate to political science methodology, but rather use traditional imitative patterns, borrowed from their masters.

They also use their own experience to educate young academic staff. The methodological guidelines from the field of political science are marginalised. They also argue frequently that political science research has not established a credible methodology, which is characteristic of all "young" scientific disciplines.

5 K. Cebul, R. Zendrowski, Wstęp do nauki o polityce, państwie i prawie, Warszawa 2006, pp. 16-17.

6 C. Mojsiewicz, Rozmowy o polskiej politologii, Toruń 2005, pp. 62-65. 
The attitude of representatives of related scientific disciplines towards political science constitutes a complex cognitive reality. A relatively peculiar dichotomy can be observed. ${ }^{7}$ On one hand, it is expressed by acceptance of political science as a young research discipline, that derives research and educational models from Western European and American reality. On the other hand, lack of acceptance can be observed due to participation of the academics in political life, including media. It is pointed out, that representatives of the discipline exchange their calling for strictly research for one devoted to commenting of political life, and at the same time turn this into an accusation of methodological nature (replacing research methods with colloquial experience of participation in socio-political life). ${ }^{8}$

A positive aspect of scientific and didactic pursuit of political science is constituted by the referrals to the newest of its challenges, to world standards. ${ }^{9}$ Among these we can observe the following: 1) the retreat from narrow empiric research and a turn towards theoretical approach or an approach that combines theory with socio-political practice; 2) departure from statistical systemic models in favour of recognising political life as one that that is constantly "becoming;" 3) recognition of social movements, activity of individuals engaged in political life; 4) attachment of great importance to recognition of value systems, discourse forms, collective mentalities, political culture; 5) usage of research methods directed to interpretations, recognitions of case studies.

Among topics of particularly big cognitive significance in political science research there are also problems located in interdisciplinary research. We can enumerate a few that require our attention: 1) processes of a simultaneous unification and diversification of cultural life, including political life; 2) european changes - the emergence of a new institutional

\footnotetext{
7 Ibidem, pp. 91-95.

8 A. Chodubski, Powołanie naukowe a potoczność uprawiania politologii, [in:] Teoretyczne i metodologiczne wyzwania badań politologicznych w Polsce, eds. A. Antoszewski, A. Dumała, B. Krauz-Mozer, K. Radzik, Lublin 2009, pp. 35-49.

9 See: S.D. Tansey, Nauki polityczne, Poznań 1997; E. Zieliński, Nauka o państwie i polityce, Warszawa 1999; V. van Dyke, Wprowadzenie do polityki, Poznań 2000; M.G. Roskin, R.L. Cord, J.A. Medeiros, W.S. Jones, Wprowadzenie do nauk politologicznych,
} 
order, including the surfacing realisation possibilities and threats; 3) realisation of the democracy idea in the reality of an emerging informational society; 4) creation of new forms of international contacts - possibilities, resistances, counteraction to civilizational political sciences; 5) migrations of population - national and ethnical modifications, changes of collective and individual mentality in the area of myths, stereotypes; 6) creation of market (marketing) culture; 7) emergence of new political and economic institutions, and consequences for culture and civilisation; 8) new subjects of cultural life - political elites, local governance structures, NGOs, security organisations; 9) New trends in management, departure from philosophy of control in favour of horizontal connections; 10) social costs of political transformation.

The scope of political science research generates the usage of different terms for this discipline. In recent years the terms politologia ("politology"), interchangeably with nauki polityczne ("political sciences"), nauka o polityce ("politics science") and studia politologiczne ("politological studies") have been used very often. These terms are not synonymous. Politology is not a so called cluster of different segments of knowledge, described as political sciences. Despite being perceived so in colloquial reception. Politology possesses an autonomy; it is designed by such integral components as: theory of politics, institutionalisation of political life, political thought, political systems, social and economical politics, international relations, political culture, holistically perceived, in mutual connections, dependencies, influences, interactions. Yet this reality requires an elaborated and coherent research methodology, including a method of political science.

In connection with this, the question of stimulating a methodological awareness in the researcher of political phenomena and processes is important.

This describes both professional self-knowledge - a researcher's selfdefinition and his methodological competence, i.e. the knowledge of

Poznań 2001; B. Szmulik, M. Żmigrodzki (eds.), Wprowadzenie do nauki o państwie i polityce, Lublin 2002; T. Żyro, Wstęp do politologii, Warszawa 2004; J. Muszyński, Podstawy nauki o polityce, państwie i prawie, Toruń 2007. 
research procedures and the practical ability to use them for cognitive purposes. ${ }^{10}$

A critical look on the awareness of Polish researchers of political science reveals dominance of descriptive approach, avoidance of formulation of scientific laws, avoidance of usage of genetic - structural, genetic functional and systemic explanations, usage of a narrow one-aspect analysis and avoidance of specification of regularities in the evolution of phenomena and processes of political life. In the face of a far-reaching mythologization of law, ${ }^{11}$ the identification of phenomena and processes situated in legal solutions, structures, currently reveals itself with a significant force. In this situation the calling for research strictly in the field of political science is replaced by simple descriptions of legal and lawrelated matters.

In an analysis of this type the general methodological principles of cognition are minimised, including situating of phenomena and processes in a long-term perspective and cultural and civilisation determinisms that reveal themselves in it, comprehensive, holistic and systemic approach to described reality, and predictivity ${ }^{12}$ (often expressed in this context is the opinion that a scientific prediction of politics' evolution is not possible; this opinion results from the lack of knowledge of scientific acquisition in the field of prognostic research, and of the methodological issues).

At the current stage of development the disciplinary distinction of political science is clear, it is not a simple sum of elements that come together to constitute it. It cannot be regarded as a sum of various other disciplines, political problems are situated at the centre of cognitive attention. The integration of knowledge within the boundaries of one discipline reveals itself as a syncretic and homogenous reality. The elements that constitute political science cannot be regarded in isolation, but rather in complete integration, tied to each other by varying links of interdepen-

10 See: M. Karwat, Status metodologiczny kategorii nauki o polityce, [in:] Wprowadzenie do teorii polityki, ed. J. Gieorgica, Warszawa 1982; Z. Pietraś, Podstawy teorii stosunków międzynarodowych, Lublin 1986.

11 See: J. Jabłońska-Bonca, Prawo w kręgu mitów, Gdańsk 1995.

12 See: T. Bodio, A. Chodubski, Politologia jako futurologia, [in:] Metafory polityki, vol. 2, ed. B. Karczmarek, Warszawa 2003, pp. 343-367. 
dence; they are not an exogenous reality, influencing the shape of political science, but rather an order involved in constituting political science. This reality has an analogous imprint on the sphere of research methods' usage. Political science is an academic discipline, the autonomy of which was recognised at the turn of the $19^{\text {th }}$ and the $20^{\text {th }}$ centuries, to which the establishment of the Department of Politic Science at the Columbia University (in the US) in 1880 contributed. The creation of a separate discipline dedicated to identification of gaining and exercising of political power at the state or locality levels and at the international stage became an academic challenge. This became reality during the interwar period. At the universities it became one of the important disciplines of research and elite education, training staff for taking on public office.

The American model of political science practicing is regarded with considerable interest in Poland. During the transformation of political system, since 1989 patterns, paradigms of theoretical and methodological research created in academic centres in the US have been used to a substantial degree; reference books have been used (frequently this revealed even a specific excess of reference to American literature, while at the same time important treatises on the given subject existing in Poland were not mentioned; reference to American literature frequently appears as political correctness).

An important step towards the formation of political science in a reductionist dimension, i.e. one that isolates it from other social sciences, was the enactment of fundamental problems generating the autonomy of the discipline politics science by the UNESCO in 1948. Among major components constituting it following have been enumerated: 1) political theory; 2) political institutions; 3) parties and socio-political organisations; 4) history of political thought; 5) international relations.

In the classification of sciences political science has been situated in the group of humanistic sciences. At that point sciences described as auxiliary were also isolated from it. Among these philosophy, history, economy, jurisprudence, organisational studies, sociology. Following this a clear aspiration to formulate the essence of so called political science method occurred, in which, starting from the essence of politics, human behaviour, attitudes and aspirations were characterised, both in an indi- 
vidual and a collective dimension. In the theoretical approach questions of functioning of state, political parties and movements, institutions of political life, political awareness and culture became vital issues.

In cultural and civilisation practice, in which the study of state was shaped after the Second World War, the tendency to establish strong bonds between it and ideological and instrumental functions was revealed. The task of forming civic attitudes had been placed before it. Diversity within political science education occurred, theoretical and methodological education was minimised in favour of ideological and internal orientation of politics in individual countries. A lot of emphasis was put on so called detailed policies, economical, social, industrial, agricultural, housing, educational, health policies among others. ${ }^{13}$ For the purpose of their analytical research a necessity to use researching methods and techniques characteristic of various areas of research arises (quantitative, comparative, behavioural, decisional, simulation studies among others).

Recent political history is an important element of political science education. Beside the identification of key events of political history of countries, the analysis of political movements, parties and international relations has become appealing. This tendency revealed itself with great force also during the transformation of political system in Poland. In a new political situation normative-legal education, concerned with sociopolitical life, became minimised in favour of revealing of so called terra incognita, the unofficial current of socio-political life strongly embedded within a mythologised reality. ${ }^{14}$

In the new situation of identifying recent history a critical attitude towards theoretical approach, dictated by research methodology, was revealed; confrontational tendencies, concerning the so called solidity of research, became apparent between representatives of various humanistic and social disciplines. A stern judgment on political science and its research within the scope of recent history was expressed by sociologists, jurists, historians. Its apologetic functions with regard to governments and ideologies were pointed out and called servile. In this situation ten-

13 A. Bodnar (ed.), Nauka o polityce, Warszawa 1988, chapter 1.

14 M. Kosman, Kultura polityczna - kultura historyczna, Poznań 2009. 
dencies appeared to modify the profile of political science towards that of empiric research, which was realised by using sociological methods and techniques for identification of socio-political phenomena and processes. As a result an important place within the structure of political science was taken by sociology of politics. Considerable cognitive interest was directed to jurisprudential models, which resulted in structural order gaining priority within political science research before value systems, attitudes, political behaviour. Even the erasing of boundaries between juristic and political science research was revealed, yet in the case of this reality there was substantial influence from the political scientists' education profile, i.e. juristic education.

It was attempted to disclaim the objection concerning the unsatisfactory state of empiric research by reaching out to methodological patterns of natural sciences. Sometimes it was attempted to implement methods and techniques rationalising the reality of culture and civilisation for the purpose of analysis of political attitudes and behaviour. The so called parameterisation of research became appealing and it resulted in a strengthening of quantitative analysis. In effect a new reality of statement formulation and means of their substantiation appeared; in identification of reality the so called common sense was being eliminated, as was intuitive empathy, both in favour of descriptive accounts, that were the result of empiric research (sociological techniques - surveys, categorised interviews). A characteristic exemplification of these tendencies was constituted by the research of Polish minorities in foreign countries. The usage of statistic and representative surveys revealed a deformed picture of the immigrants' lives. Even the very definition of their identity turned out to be a complicated matter, which was generated by processes of adaption, integration and assimilation..$^{15}$ In this situation methodological knowledge was commenced to being replaced by a master with authority in the field, as a competent creator of knowledge. A dilemma revealed itself in connection with this though: who ought to be considered authority in science,

\footnotetext{
15 A. Chodubski, Contemporary Polish emigration: barriers and possibilities, "Dialogue and Universalism” 2000, No. 1; idem, Tożsamość Polaków w rzeczywistości diasporalnej, [in:] Wspólne drogi Polaków w kraju i na obczyźnie (1918-2008), eds. L. Kasprzak, M. Szczerbiński, Piła 2009, pp. 375-389.
} 
since outstanding individuals isolate themselves from public political life (closet scientists)? Can individuals deeply and actively involved in sociopolitical life, with educational and professional experience gained in the country or in the Western European cultural area, with many publishing credits or present in the public awareness through media promotion, as those who speak in favour or against something, be considered that kind of authority? The problem of academic degrees and titles also revealed itself with connection to this. This reality started to be linked to the ideological and political domain. Yet, in spite of the so called media buzz, the opinion persist, that an academic without scientific and publishing credits is not a creative research worker, and that academics, who have not underwent the complete path of academic degrees' acquisition, may be deserving academic educators, but they should not function as scientific researchers. It is recognisable, that the system of academic degrees is an important instrument for protection of the level of science-research profession.

In the transformational reality of Poland the generational problem of academics revealed itself with great force. A noticeable tendency to entrust very young adepts of science and education with positions connected to organisational tasks in science and academic life was observed. Very often the criterion for these selections was involvement in processes of political change. This reality had a vital impact on the formation of the political science discipline's countenance. Above all by selectively adopting patterns, which are used for practising of political science on Western European universities. Processes occurring at the same time revealed themselves. On one hand, the unification of political science development was taking place, with the discipline clearly establishing its autonomy. In this unification worldwide standards of political science practising were evident. On the other hand, a deep diversification, pluralisation of development took place. The so called individually designed academic courses with a remarkably wide spectrum and different degrees of relevance for politics science were introduced into education. This disintegration was stopped by the introduction by the government ministry of the so called programmatic minimums, in which the necessity of general, major course, disciplinary and specialising education was pointed out. 
Fundamental standards of education have been defined. In a situation of dispersion of political science education centres a tendency to abandon methodological and theoretical problems in favour of immediate needs of political practice, among others in the sphere of political marketing, socio-political communication, local government, social work, diplomacy, has revealed itself. This was justified by the needs of labour market, the challenges concerning the improvement of employees' qualifications in public life institutions. This reality soon generated new types of behaviour: 1) political correctness ousted the truth about a given reality; 2) scientific persons of authority were replaced by celebrities (a young, physically attractive, rich teacher, who uses information technology equipment, frequents the Western European reality of culture and civilisation); 3) in-depth evaluations of attitudes and behaviour were replaced by opinion polls.

This reality began to generate an obliteration of boundaries between: 1) the truth and reality on one side and scenery and spectacle on the other; 2) information and disinformation, manipulation; 3) personality and created image.

Traditional values are replaced by a commercial market reality; wisdom - market skills, commercial skills; wisdom - capabilities; competence - media skills; ethics, morality - effectiveness. ${ }^{16}$ Under the conditions of these changes the society displayed a considerable interest in political education. It became a mass reality. Organisational considerations led to its divisions in departments and specialisations. Consequence of mass interest in education was a further decrease of interest in methodology and theory of politics, albeit the indication of necessity to link theory with socio-political practice became an appealing motto at that time. In many academic centres scientific conferences, devoted to methodological questions, were organised. They have fully displayed that this is a marginalised sphere in political science education, that it is not fully understood both within the scope of research and in the didactic process.

In the contemporary political science discourse the role of theoretical studies is emphasised, they are considered to be the foundation of the

16 E. Polak, Globalizacja a zróżnicowanie społeczno-ekonomiczne, Warszawa 2009, p. 233. 
discipline's development. It is recognised that a discipline, which is not able to present theoretical approaches to its subject-matter and research scope, loses its raison dêtre to situate itself within science.

For theory is a systematic, critical and orderly reflection of phenomena and processes, which constitute the subject-matter of cognition. It identifies, defines and outlines the boundaries of cognition.

Every scientific discipline has its methods, which it uses to identify a given reality of culture and civilisation. Methods understood as paths leading to identification of particular phenomena and processes are usually situated within the interdisciplinary order, albeit as research tools they have to be directed at precisely defined disciplinary cognition, e.g. in the behavioural approach of political science the attention is directed at materialisation of institutions of power; in the sociological approach at attitudes, behaviour, relations between humans; in psychological approach at goals, personality features generating particular phenomena and processes in life of culture and civilisation.

The method of each discipline, including political science, is contained within a specific procedure, the links of which are: 1) formulation of cognitive problem; 2) admission of possible response alternatives; 3 ) thinking process about what type of facts and events may be able to shed light on the essence of the problem, and what way can they be acquired, gathered in an useful configuration; 4) gathering of facts, information vital for the problem being identified; 5) formulation of a hypothetical solution to the problem, according to expectations; 6) verification of research findings with use of different variables, while observing the precise rules of classification. During these proceedings a political scientist ought to combine the analysis of information gained empirically with knowledge about the past (about phenomena and processes) and deduction. For political science analysis is a strategy to synthesise the results acquired from empiric research in combination with theoretical understanding (expressed among others by usage of terms, categories), within the order of general research procedures. Deduction plays an important role on both the explanatory and predictive level of cognition.

From methodological point of view political science analysis is a strategy for research of political life, especially the contemporary one. Follow- 
ing challenges are important for this strategy: 1) supply of reliable knowledge about identified phenomena and processes, which can be useful for political activity of various subjects; 2) conduct of research with accordance to definite rules and models (expressed among others by survey questionnaires and by other tools of source material acquisition); 3) reference of source material analysis to theoretical thought, concerning among others the essence, tasks and goals of politics; 4) reporting of research findings; directing its attention at systemic, generalising, analytical and exemplificational approaches.

Observing the contemporary development of science, including humanistic and social disciplines, it can be stated with confidence that political science, in spite of a manifesting dispute about the homogenous or integral paradigm of development, meets the challenge to possess an autonomic method, which is called political science method. The point of departure for its conceptualisation is the theory of politics.

The distinguishing marks of the method are:

1. Implementation of terms and categories from political science in order to explain a given reality of culture and civilisation;

2. Usage of political science theories from the domain concerned with gaining, exercising and keeping of power in relation to the entirety of cultural life phenomena and processes;

3. Connection of theoretical knowledge with empirics and practice of socio-political life. Usage of general cognitive thought in relation to this - why did the given merits, phenomena, processes come to existence; indication of general regularities of a given reality's development;

4. Placing of political phenomena and processes in a long-time perspective, which allows to distinguish their regularities or specifics;

5. Analysis of a becoming reality, current phenomena and processes in the life of culture and civilisation, from the point of view of socio-political life's institutionalisation;

6. Usage of models, patterns, paradigms elaborated by the world's political science with reference to the identified reality of culture and civilisation, which is generated in a given time and space; 
7. Transformation of a colloquial reception of the world and condition of man in the world of politics into a systematised, structural, holistic reality of culture and civilisation;

8. Grasping of integral activities of communities and individuals in identification of political phenomena, facts and processes in dynamics of global changes and of these activities' results, in addition to rational and causative clarification of attitudes, behaviour, aspirations of a society in a given time and space;

9. Indication of correlations, links, interdependencies, influences, interactions that occur in socio-political activities, generated by various subjects of cultural life;

10. Substantial degree of consideration in identifying of socio-political reality for the predictive calling of science, the detection and prediction of evolutional tendencies in the life of culture and civilisation, including especially those concerning political life.

At the contemporary level of political science's development this method should not eliminate other methodological approaches directed at achievement of information about the world, especially about sociopolitical reality. This is connected with the fact that society distances itself considerably from scientific knowledge, including that about politics, which is regarded in a dimension of great identification, unsuited for implementation in the immediate political practice. A substantial scepticism towards the scientific knowledge of political elites also reveals itself. In the world of science it is not possible though to accept the colloquial understanding of politics only. The fundamental challenge for a political scientist is the creation of theory, even in a situation where it remains in the sphere of mute knowledge.

The method of political science presents a great auxiliary value to the commentators of political life. It consolidates them in explaining of phenomena from theoretical point of view, including both defining and situating in the perspective of culture's and civilisation's pragmatism. Interpretations and evaluations refer to models, paradigms of cultural life's development in time and space.

The problem of political life's valuation reveals itself at this juncture; on one hand the methodological postulate to free science from valuations 
is clear, on the other hand - researchers are expected to express judgments, evaluations, opinions both about the legacy of political past and the becoming reality. This situation concerns not only humanistic sciences. In the information society currently under formation it is noticeable, that the pursuit of science as a mission, a calling (often of a single human being) is part of cultural legacy. Currently it is becoming one of the performed professions. Specific tasks are being assigned to it, which it fulfils, thus contributing to the development of the world's civilisation. It is being observed that science loses its freedom in this reality, that it becomes a specific productive force. The evolutional character of political life constantly supplies researchers with new practical tasks, which they identify, interpret, usually according to the challenges of political correctness.

As a general afterthought the following can be stated:

1. In the development of Polish political science methodological questions are a marginalised reality; they are mentioned in the dimension of so called intellectual correctness, and not in accordance with a scientific calling.

2. The method of political science is regarded in the dimension of becoming, which results above all from the identity of political science - the perception of this discipline as homogenous, in possession of its own autonomy, or from the interdisciplinary vision, its perception as the object of research by various disciplines connected by a common domain, i.e. the sphere of political life.

3. The identity of the discipline politology is to a considerable degree determined by the considerations of cultural practice, the interest for political science education and the need to supply applicable knowledge for the development of socio-political institutionalisation.

4. The political method has a clearly determined, own autonomy in the system of humanistic and social science's methodology. It does not however enjoy a full acceptance, neither in the endogenous, nor in the exogenous dimension. To a considerable degree this is determined by the tradition of political science's and its methodology's development. 
5. In the prognostic vision it is noticeable, that its positive development reveals itself, which results from the formation of new staff in political science (and not of amateurs pursuing this discipline), from creation of links to a vast institutionalisation of development of research and political science's education, and also from acceptance of the directions of the contemporary political science research by representatives of other disciplines, including those related from the point of view of the cognition's subject-matter. 